\title{
EVALUASI PROGRAM PENGEMBANGAN KEWIRAUSAHAAN (PPK) DI INSTITUT SAINS \& TEKNOLOGI AKPRIND YOGYAKARTA
}

\author{
Evaluation Of Entrepreneurship Development Programs (PPK) \\ In Institut Sains \& Technology AKPRIND Yogyakarta
}

\author{
Muhammad Yusuf $^{1 *}$, Beny Firman ${ }^{2}$ \\ ${ }^{1}$ Jurusan Teknik Industri, Jurusan Teknik Elektro, Fakultas Teknologi Industri, \\ Institut Sains \& Teknologi AKPRIND Yogyakarta, \\ Jl. Kalisahak 28 Kompleks Balapan, Yogyakarta 55222 \\ * Penulis Korespodensi : yusuf@akprind.ac.id
}

\begin{abstract}
ABSTRAK
Program Pengembangan Kewirausahaan (PPK) merupakan usaha untuk menumbuhkan minat mahasiswa berwirausaha. Peran perguruan tinggi dalam mempersiapkan wirausaha pada hakikatnya persiapan kader wirausaha dalam segi penempaan karakter wirausaha. Dengan maksud lain, persiapan mahasiswa untuk melaksanakan wirausaha terletak pada penempaan semua daya kekuatan pribadi mahasiswa itu untuk menjadikannya dinamis dan kreatif, di samping mampu berusaha untuk hidup maju dan berprestasi, mengasah jiwa wirausaha, meningkatkan soft skill dengan terlibat langsung di dunia kerja, dan berani membuka usaha serta cakap, terampil menumbuhkan sense of business sehingga tercipta wirausaha muda potensial berbasis ipteks. Evaluasi kegiatan ini berfungsi memberi gambaran terhadap obyek yang diteliti melalui pengumpulan data terhadap populasi. Data diperoleh dari hasil kuisioner, wawancara dan observasi langsung di lapangan terhadap obyek penelitian. Sumber data adalah pengelola kegiatan PPK, dosen pembimbing kelompok usaha (tenant), dan mahasiswa kelompok usaha (tenant). Analisis data menggunakan teknik analisis deskriptif dengan penyajian data menggunakan pictogram, rata-rata (mean), simpangan baku (standart deviasi), skor maksimum dan minimum. Validitas dan reliabilitas instrument dianalisis menggunakan alpha cronbach's. Hasil akhir pelaksanaan program PPK adalah 1) pengelolaan administrasi rerata 3,143 kategori baik. 2) pelaksanaan kegiatan rerata 3,452 kategori baik. 3) pencapaian tujuan rerata 3,193 kategori baik. 4) tindak lanjut pendampingan program rerata 3,578 kategori baik. Faktor pendukung program PPK adalah aspek pemahaman program, meningkatkan kemampuan dan pengalaman menyelenggarakan merupakan faktor pendukung sedangkan fakor penghambat adalah dana block grant yang diberikan pemerintah lambat, waktu yang kurang, minimnya dana stimulan untuk membuka usaha, sulitnya mencari sumber dana dari tempat lain.
\end{abstract}

Kata Kunci : Evaluasi, PPK, Wirausaha, Mahasiswa

\begin{abstract}
The Entrepreneurship Development Program (PPK) is an effort to foster interest in entrepreneurial students. The role of universities in preparing entrepreneurship is essentially the preparation of entrepreneurial cadres in terms of forging entrepreneurial character. With other intentions, the preparation of students to carry out entrepreneurship lies in forging all of the students' personal power to make it dynamic and creative, in addition to being able to strive to live ahead and excel, hone the entrepreneurial spirit, improve soft skills by being directly involved in the world of work, and brave opening a business and competent, skilled in growing a sense of business so as to create potential young entrepreneurs based on science and technology. Evaluation of this activity serves to give an overview of the object under study through data collection on the population. Data obtained from the results of questionnaires, interviews and direct observation in the field against the object of research. Data sources are PPK activity managers, business group supervisors (tenants), and business group students (tenants). Data analysis used descriptive analysis techniques with data presentation using pictogram, mean (mean), standard deviation (standard deviation), maximum and minimum scores. The instrument validity and reliability were analyzed using alpha cronbach's. The final results of the PPK program implementation are 1) average administrative management of 3,143 good categories. 2) the average implementation of 3,452 good categories. 3) achieving the average goal of 3,193 good categories. 4) follow-up assistance for 3,578 average good category programs. Factors supporting the PPK program are aspects of understanding the program, increasing the ability and experience of organizing is a supporting factor
\end{abstract}

M. Yusuf., Beny F., EVALUASI PROGRAM PENGEMBANGAN...

Available at http://jurnal.borneo.ac.id/index.php/jpmb 
while the inhibiting factors are the block grant funds given by the government slow, lack of time, lack of stimulant funds to open a business, difficulty finding sources of funds from other places.

Keywords: Evaluation, PPK, Entrepreneurship, Students

\section{PENDAHULUAN}

Perguruan tinggi baik negeri atau swasta selain dituntut menguasai keilmuan sesuai bidangnya, juga dituntut dapat menguasai teknologi terkini serta memiliki soft skill yang baik sehingga mampu bersaing dengan lulusan dari perguruan tinggi lain baik dalam maupun luar negeri. Intitut Sains \& Teknologi AKPRIND Yogyakarta saat ini telah berbenah diri dalam membekali mahasiswa dengan harapan lulusannya tidak lagi sebagai pencari kerja (job seeker) atau menjadi penganggur tetapi menjadi pencipta pekerjaan (job creator). Berbagai usaha telah dilakukan di antaranya dengan membuka usaha kreatif baik dalam bidang koperasi, las, berbengkelan, jasa elektronik, kulier, dan lainnya. Usaha tersebut diyakini secara tidak langsung dapat menumbuhkan jiwa wirausaha di lingkungan kampus, juga memberi bekal yang dapat digunakan oleh mahasiswa untuk mengembangkan jiwa wirausaha.

Kewirausahaan adalah kegiatan kreatif, inovatif, dan terorganisir dalam menciptakan produk baru dan pasar baru yang disertai keberanian mengambil risiko atas hasil ciptaannya dan melaksanakannya secara terbaik (ulet, gigih, tekun, progresif, pantang menyerah) sehingga nilai tambah yang diharapkan dapat dicapai (Asep Saefullah, dkk., 2011). Kewirausahaan tidak cukup hanya menemukan produk baru, tetapi juga harus mampu memasarkan produk/ide barunya ke dunia nyata dan ini memerlukan kemampuan memasarkannya (Hisrich, R.D, dkk., 2008). Kegiatan kewirausahaan juga melibatkan pengambilan risiko karena produk maupun ide baru yang dihasilkan belum jelas masa depannya.

Pendekatan yang digunakan PPK dalam konteks pemberdayaan potensi entrepreneurship mahasiswa menggunakan metode PALS (Participatory Action Learning System). Prinsip dasar dari metode PALS adalah pelibatan mahasiswa dalam proses pembelajaran aktif partisipan dalam program kewirausahaan (entrepreneurship) secara alamiah dengan segala pendekatan sehingga membentuk suatu sistem interaksi pembelajaran secara partisipatif, baik secara personal maupun komunal (Ciputra, 2009).

Metode PALS menitik beratkan pada transformasi kegiatan-kegiatan yang telah ada untuk diusahakan dibawa pada perubahan-perubahan ke arah perbaikan kondisi entrepreneurship mahasiswa melalui (1) fase penyadaran kewirausahaan (awareness), merupakan starting point dalam membangun kapabilitas wirausaha mahasiswa melalui recruitment dan test kewirausahaan (entrepreneurship). (2) fase pengkapasitasan (capaciting) dan pendampingan (scaffolding) kewirausahaan (entrepreneurship capacity building), diharapkan dapat menghantarkan mahasiswa untuk menghasilkan rencana usaha bisnis (bussines plan) yang matang untuk diimplementasikan dalam membuka usaha baru (start-up bussines).Pola pembimbingan dan pengawasan pada fase pengkapasitasan kewirausahaan ini dilakukan secara terpadu dengan melibatkan tim pelaksana PPK, bagian kemahasiswaan, dan nara sumber (dosen pembimbing) dengan mengoptimalkan 
monev internal dan (3) fase pelembagaan (institutionalization) usaha baru sebagai wirausana baru.

Kerberhasilan PPK dapat dilihat dari pelaksanaan berdasarkan keberhasilan programnya yang terukur. Agar pengukuran keberhasilan program tepat dan dapat dipertanggungjawabkan, maka indikatornya harus jelas. Indikator tersebut selanjutnya dijadikan dasar penyusunan instrumen penilaian program. Indikator tersebut adalah: 1) Administrasi yang terdiri atas penilaian, pengelolaan dan pembiayaan, 2) Pelaksanaan program yang terdiri atas kurikulum/materi, proses pembelajaran, dosen pembimbing, dan mahasiswa sebagai tenant 3) Pencapaian tujuan terdiri atas kecakapan hidup tenant dan sarana prasara, 4) Follow up (tindak lanjut) terdiri atas bentuk dan intensitas pendampingan dan penilaiannya, 5) Penghambat dan pendukung terdiri atas faktor penghambat dan pendukung pelaksanaan program. (Moerdiyanto, 2010)

\section{METODE}

Data dalam penelitian ini berupa angket digunakan untuk menjaring data pengelola PPK, dosen pembimbing kelompok usaha (tenant), mahasiswa sebagai tenant, juga wawancara untuk menjaring data pada pengelola PPK untuk mengetahui kesiapan pengelolaan dalam pelaksanaan program PPK (lihat gambar 1). Model wawancara bersifat tertutup, dokumentasi untuk mengatahui data-data tentang persiapan pengelola, identitas peserta, pengelola, kualifikasi dosen pembimbing, laporan, sukses story, laporan keuangan.

Data yang terkumpul kemudian dianalisis dengan menggunakan teknik analisis deskriftif kuantitatif yaitu mendiskripsikan dan memaknai tiap-tiap komponen data evaluasi kemudian dibandingkan dengan acuan kreteria yang telah ditentukan sebelumnya berdasarkan rata-rata ideal dan simpangan baku ideal yang dicapai oleh instrumen.

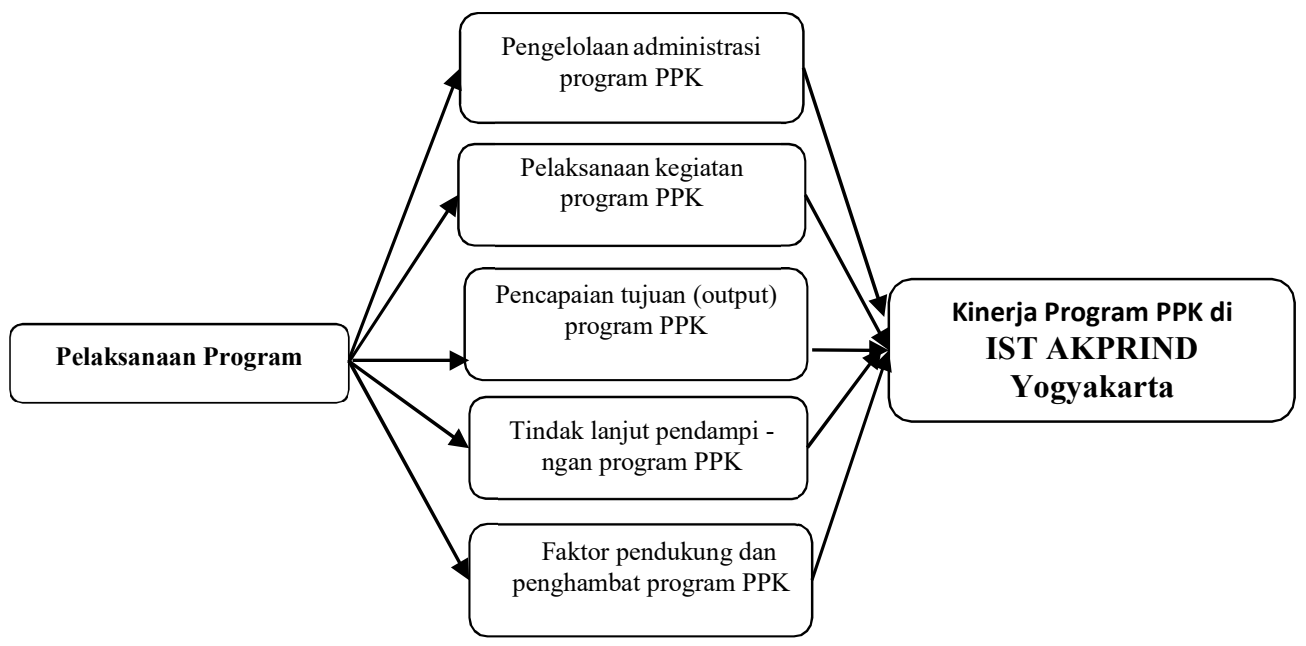

Gambar 1. Kerangka Berfikir Pemecahan Masalah

Penafsiran pelaksanaan program PPK dengan menggunakan tabel interprestasi rata-rata (mean), simpangan baku (standart deviasi), skor maksimum dan minimum diperoleh melalui bantuan program SPSS
13.0 for Windows. Kemudian hasil perhitungan tersebut ditafsirkan dengan kreteria seperti pada tabel 1 (Arikunto, dkk., 2009). 
Tabel 1. Kreteria Penafsiran Efektivitas Program

\begin{tabular}{ll}
\hline Nilai Skor & Interpretasi \\
\hline $\mathrm{X} \geq \mathrm{Mi}+1,5 \mathrm{SD}$ & Sangat Baik \\
$\mathrm{Mi}+0,5<\mathrm{X}<\mathrm{M}+1,5 \mathrm{SD}$ & Baik \\
$\mathrm{Mi}-0,5 \mathrm{SD}<\mathrm{X}<\mathrm{Mi}+0,5 \mathrm{SD}$ & Cukup Baik \\
$\mathrm{Mi}-1,5 \mathrm{SD}<\mathrm{X}<\mathrm{Mi}-0,5 \mathrm{SD}$ & Kurang \\
$\mathrm{X}<\mathrm{Mi}-1,5 \mathrm{SD}$ & Sangat kurang
\end{tabular}

Keterangan:

$\mathrm{Mi}=$ rata-rata ideal komponen dalam penelitian, dengan rumus $=1 / 2($ skor ideal tertinggi dalam komponen + skor ideal terendah).

$\mathrm{SD}=$ standart deviasi ideal dalam setiap komponen penelitian, dengan rumus 1/6 (skor ideal tertinggi dalam komponen - skor ideal terendah).

\section{HASIL DAN PEMBAHASAN}

Hasil perolehan rerata skor pelaksanaan PPK di IST AKPRIND Yogyakarta, secara terperinci dapat dilihat pada paparan berikut ini.

\section{a. Pelaksanaan Pengelolaan}

\section{Administrasi PPK}

Pada pengelolaan administrasi program PPK terdiri dari tiga indikator yaitu penilaian adminitrasi, pengelolaan, dan pembiayaan. Sub indikator penilaian administrasi terdapat dua. Sub indikator pengelolaan ada enam. Sub indikator pembiayaan ada empat.Pada pengelolaan administrasi program PPK terdiri dari 29 butir pertanyaan setelah dianalisis reliabilitas dengan alpha cronbach's didapatkan hasil $0.938>0.600$ sehingga

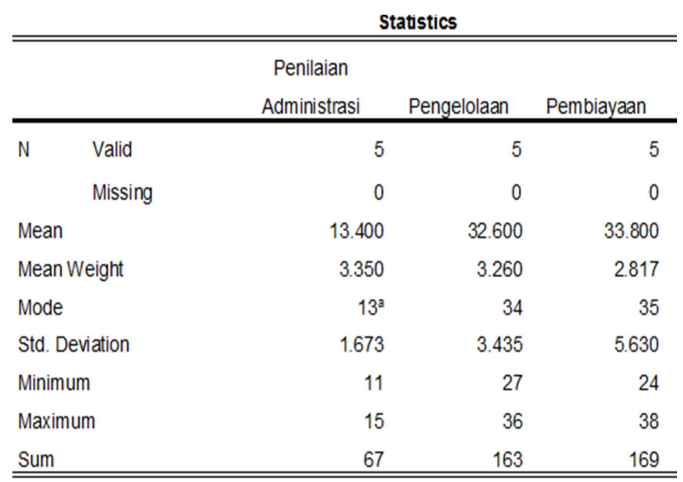

a. Multiple modes exist. The smallest value is shown

Gambar 2. Hasil Pengelolaan Administrasi Program PPK instrument dinyatakan reliabel. Sedangkan validitasnya masing-masing butir diperoleh angka 0,935 sd 0 , 0941>0.400 dinyatakan valid. Setelah intrument digunakan untuk mengambil data kemudian dianalisis hasilnya adalah sebagai berikut penilaian administrasi program dengan skor rata-rata median sebesar 3,350. Pengelolaan program sebesar 3,260 dan pembiayaan sebesar 2,816. Sehingga rata-rata hasil pengelolaan administrasi program PPK sebesar 3,143 dikategorikan baik. Berikut ini adalah gambar histogram dari pelaksanaan administrasi program PPK di IST AKPRIND Yogyakarta (Gambar 2).

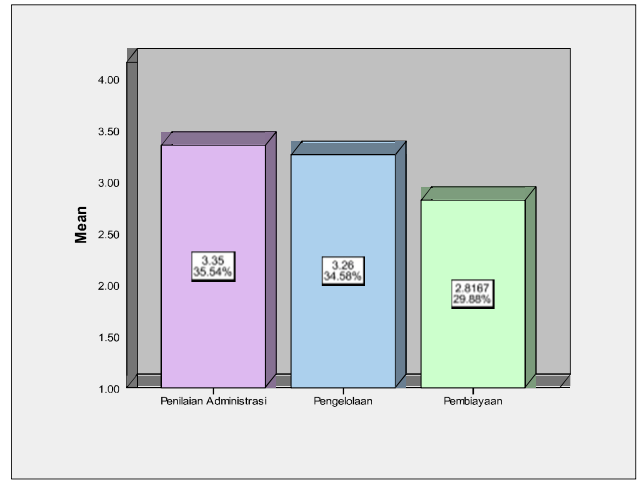




\section{b. Pelaksanaan kegiatan program PPK}

Dalam pelaksanaan kegiatan PPK terdapat lima indikator yaitu 1) kurikulum, 2) proses pembelajaran, 3) dosen pembimbing 4) mahasiswa/tenant, 5) sarana dan prasarana. Lima idikator utama tersebut kemudian dijabarkan dalam sub indikator. Indikator kurikulum terdapat 3 sub indikator, indikator proses pembelajaran terdapat 7 sub indikator, idikator dosen pembimbing tenant terdapat 3 sub indikator dan indikator mahasiswa/tenant terdapat 2 sub indikator, dan indikator sarana dan prasaran terdapat 4 sub indikator.

\begin{tabular}{|c|c|c|c|}
\hline & & Kurikulum & $\begin{array}{c}\text { Proses } \\
\text { Pembelajaran }\end{array}$ \\
\hline \multirow[t]{2}{*}{$N$} & Valid & 9 & 9 \\
\hline & Missing & 0 & 0 \\
\hline \multicolumn{2}{|c|}{ Mean } & 19.556 & 45.444 \\
\hline \multicolumn{2}{|c|}{ Mean Weight } & 3.259 & 3.496 \\
\hline \multicolumn{2}{|c|}{ Mode } & 19 & $40^{3}$ \\
\hline \multicolumn{2}{|c|}{ Std. Deviation } & 2.506 & 4.275 \\
\hline \multicolumn{2}{|c|}{ Minimum } & 16 & 40 \\
\hline \multicolumn{2}{|c|}{ Maximum } & 24 & 50 \\
\hline \multicolumn{2}{|c|}{ Sum } & 176 & 409 \\
\hline
\end{tabular}

a. Multiple modes exist. The smallest value is shown

Gambar 3. Hasil Kurikulum dan Proses Pembelajaran Kegiatan PPK
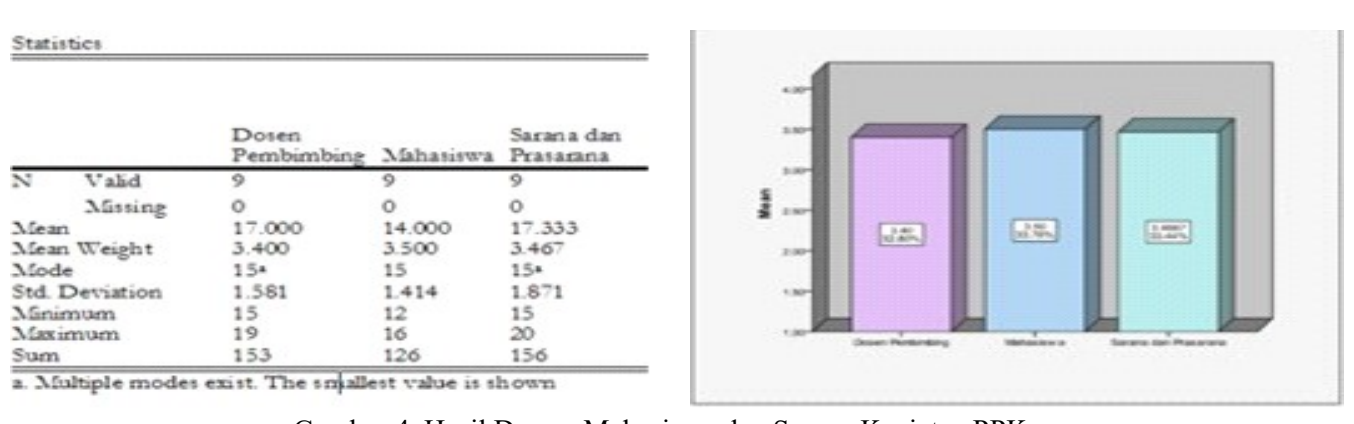

Gambar 4. Hasil Dosen, Mahasiswa dan Sarana Kegiatan PPK

\section{c. Pencapaian tujuan (output) program PPK}

Dalam pencapaian tujuan program PPK terdapat 2 indikator yaitu 1) kecakapan hidup mahasiswa/tenant, 2) sarana dan prasarana. Dua idikator utama tersebut kemudian dijabarkan dalam sub indikator. Indikator kecakapan hidup mahasiswa/tenant terdapat 7 sub
Tingkat reliabilitas dan validitas instrument dari 35 pertanyaan tersebut adalah sebesar $0,838>0,600$ dan 0.821 sd $0,871>0,400$ sehingga layak digunakan untuk mengambil data peneltian. Hasil analisis data didapatkan skor rerata untuk kurikulum 3, 259, proses pembelajaran 3,496 (lihat Gambar 3), aktivitas dosen pembimbing tenant 3,400, mahasiswa/tenant 3,500, dan sarana dan prasarana 3,467 (lihat Gambar 4). Skor rerata untuk pelaksanaan kegiatan PPK sebesar 3,452 kategori baik.

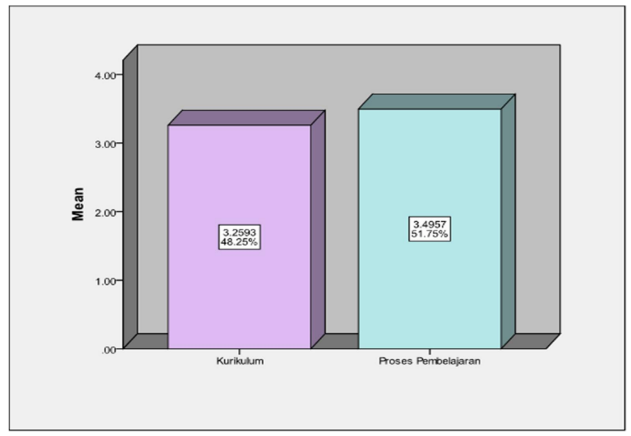

M. Yusuf., Beny F., EVALUASI PROGRAM PENGEMBANGAN... 
sarana dan prasarana 3,208. Skor rerata untuk pencapaian tujuan (output) Statistics

\begin{tabular}{|c|c|c|c|}
\hline & $\begin{array}{l}\text { Kecakapar } \\
\text { Hidup } \\
\text { Mahasiswa } \\
\text { / Tenant }\end{array}$ & $\begin{array}{l}\text { Sarana dan } \\
\text { Prasarana }\end{array}$ & $\begin{array}{l}\text { Pencapaian } \\
\text { Tujuan/ } \\
\text { Output } \\
\text { Program } \\
\text { IbK }\end{array}$ \\
\hline N Valid & 45 & 45 & 45 \\
\hline Missing & 0 & 0 & 0 \\
\hline Mean & 34.867 & 51.333 & 86.200 \\
\hline $\begin{array}{l}\text { Mean weignt } \\
\text { Mode }\end{array}$ & 38 & $\begin{array}{l}3.208 \\
509\end{array}$ & $\begin{array}{l}3.193 \\
79 a\end{array}$ \\
\hline Std. Deviation & 13.800 & 5.768 & 6.904 \\
\hline Minimum & 26 & 39 & 73 \\
\hline Maximum & & 63 & 100 \\
\hline Sum & 1569 & 2310 & 3879 \\
\hline
\end{tabular}

Gambar 5. Hasil Pencapaian Tujuan (Output) dari PPK program PPK sebesar 3,193 kategori baik (lihat Gambar 5).

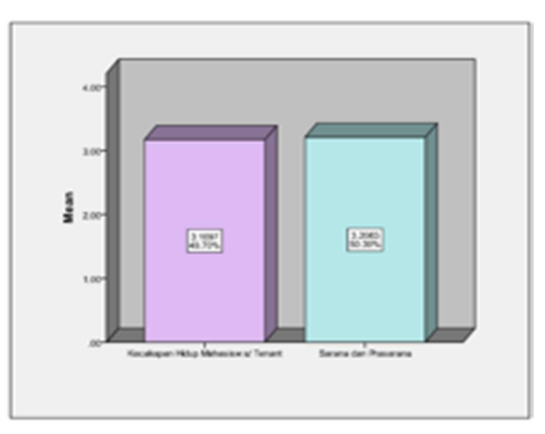

angka pengganguran dan rendahnya lowongan kerja yang ada. Perguruan tinggi yang terpaku pada upaya pemberian pembekalan knowledge dan teknologi terbukti secara empirik telah menimbulkan kemampuan penetrasi usaha bagi lulusan perguruan tinggi. Melalui pelaksanaan hibah PPK, yang fokus sasarannya adalah mencetak wirausaha baru dengan beragam variasi komoditas usaha, merupakan dasar bagi pengembangan atmosfir kewirausahaan di IST AKPRIND. Kondisi usaha mahasiswa sebelum menjadi tenant PPK banyak mengalami hambatan di dalam produksi karena kurangnya sentuhan ipteks, dan marketing karena kurangnya kemampuan dalam penetrasi pasar. Di lain pihak, tingginya tuntutan untuk tugas-tugas akademik mahasiswa, maka pelayanan salah satu tenant PPK mendapat respon yang cukup antusias di kalangan mahasiswa dan dosen. Keberlanjutan program PPK AKPRIND wajib ditindak lanjuti tim PPK dibawah koordinasi Lembaga Pengembangan Kompetensi dan Karir yang didalamnya terdapat pusat pengembangan teknologi tepat guna dan kewirausahaan melalui beberapa kebijakan dan program teknis, yakni 1) mengusulkan ke rektorat secara melembaga satus unit Inwub PPK yang 
ada sekarang dapat ditetapkan sebagai embrio untuk pusat pengembangan kewirausahaan di AKPRIND, 2) membuat kerjasama dengan pihak praktisi wirausaha/swasta sebagai lembaga mitra PPK dalam pengembangan budaya kewirausahan berlandaskan pada kerjasama yang bersifat mutual-benefide cooperative, dan 3) mengembangkan sistem monev dan audit internal yang konstruktif secara vertikal maupun horizontal, sehingga dapat dideteksi secara dini peluang kegagalan/hambatan dalam menjalankan usaha bisnis. maupun usaha bisnis yang dijalankan mahawasiswa sebagai wirausaha baru.

Berdasarkan pengumpulan data hasil penelitian pada aspek sumber daya manusia baik dalam aspek pelaksana, dosen pembimbing dan mahasiswa sebagai tenant dalam pelaksanaan program PPK dari segi pemahaman program, meningkatkan kemampuan, pengalaman melaksanakan program, dukungan institusi merupakan faktor pendukung yang perlu dipertahankan. Sedangkan faktor penghambat yang dialami oleh pelaksana PPK adalah 1) kurang koordinasi intern dan ekstern, organisasi masih kurang maksimal, kesibukan personil. 2) dosen pembimbing kelompok usaha mahasiswa tenant, kualitas penguasaan materi kurang karena hanya mengandalkan keterampilan alami, sibukan dosen pembimbing dalam melakukan pekerjaan lain, 3) mahasiswa sebagai tenant, terdapat permasalahan: motivasi yang tidak konsisten, kendala penentuan waktu belajar, kecenderungan tenant yang serba ingin cepat memperoleh keuntungan.
Penyempurnaan program PPK dapat dilakukan dengan mengembangkan program kemitraan dan kerjasama dengan pelaku bisnis di luar kampus. Iklim dan budaya akademis di Perguruan Tinggi, khususnya AKPRIND yang mengedepankan unsur birokrasi dan struktural merupakan hambatan socio-psichology yang dapat mengukung kreativitas dalam berwirausaha. Atas dasar itu, maka perlu adanya proses akulturasi budaya usaha antara dunia bisnis di luar kampus dengan embrio bisnis di dalam kampus melalui proses asimilasi dan akomodasi kerjasama yang berlandaskan pada pondasi mutual-benefide cooperative. Dua polarisasi dunia bisnis ini dapat dintegrasikan dalam program PPK dengan memperkecil sekat ruang dunia kampus dengan dunia bisnis, melalui proses internalisasi aktivitas wirausaha komunitas kampus dengan bisnis nyata di luar kampus.

\section{f. Foto kegiatan}

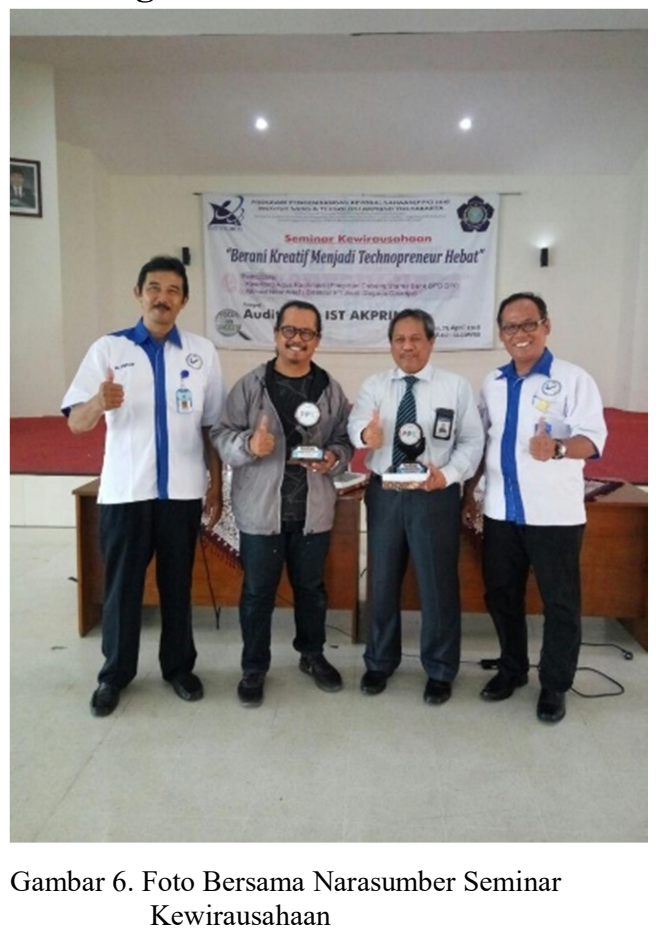




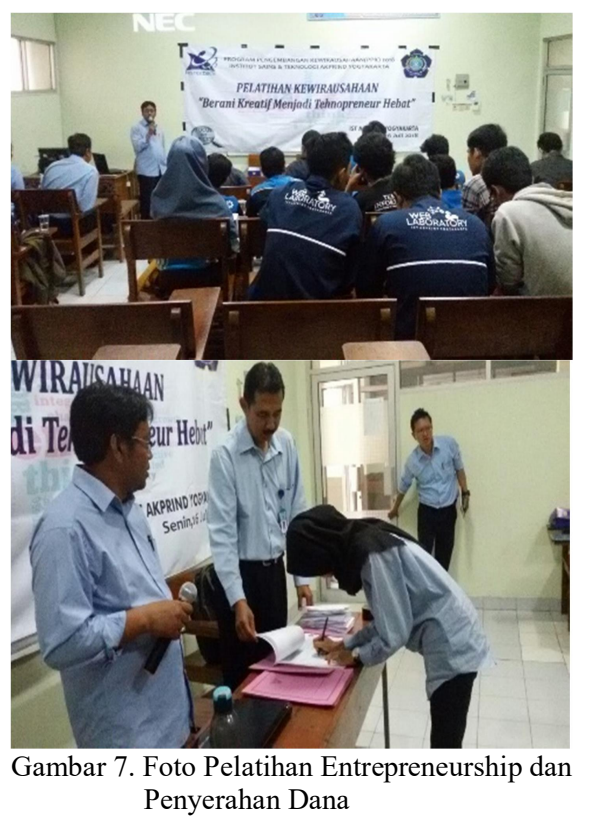

\section{PENUTUP}

Kesimpulan yang dapat diambil berdasarkan hasil penelitian dan pembahasan adalah sebagai berikut:

1. Pengelolaan administrasi program, pelaksanaan program, tindak lanjut pendampingan program, pencapaian tujuan (output) program PPK di IST AKPRIND pada kategori baik. Baiknya seluruh indikator tersebut dikarenakan dosen pembimbing tenant dan mahasiswa sebagai tenant sudah mempuyai pemahaman yang cukup terhadap konsep PPK.

2. Keberlanjutan program PPK AKPRIND ditindak lanjuti tim PPK dibawah koordinasi Lembaga Pengembangan Kompetensi dan Karir AKPRIND yang didalamnya terdapat pusat pengembangan teknologi tepat guna dan kewirausahaan melalui beberapa kebijakan dan program teknis, sehingga tenant-tenat yang sudah mandiri terpantau dan berkembang.

3. Faktor pendukung program PPK adalah aspek sumber daya manusia yang terdiri dari aspek pemahaman program, meningkatkan kemampuan dan pengalaman menyelenggarakan merupakan faktor pendukung, sedangkan sebagai fakor penghambat adalah kurang memadai jaringan akses internet dan buku-buku pendukung.

\section{UCAPAN TERIMA KASIH}

Tim pengelola PPK IST AKPRIND Yogyakarta mengucapkan terimakasih yang setulus-tulusnya kepada Rektor IST AKPRIND Yogyakarta yang telah membantu stimulan dana pendamping dan DP2M Ristek Dikti yang telah mendanai pelaksanaan kegiatan PPK tahun ketiga ini sehingga dapat berjalan dengan baik dan lancar.

\section{DAFTAR RUJUKAN}

Arikunto, Suharsimi. \& Cepi Safruddin AJ. (2009). Evaluasi program pendidikan. Pedoman praktis bagi mahasiswa dan praktisi pendidikan, Bumi Aksara, edisi kedua. Jakarta.

Asep Saefullah, Sudaryono, PO Abas Sunaryo, (2011), Kewirausahaan, CV. Andi Ofset, Yogyakarta.

Ciputra. (2009). Ciputra Quantum Leap: Entrepreneurship, Mengubah Masa Depan Bangsa dan Masa Depan Anda. Entrepreneurship Centre, Universitas Ciputra.

Hisrich, R.D, Peters, M.P ., \& Shepherd, D.A (2008). Enterpreneurship, Mc Graw hill, International edition.

Moerdiyanto. (2010). Pedoman Praktik Kewirausahaan Untuk Lembaga Pendidikan. Yogyakarta. Direktorat tenaga kependidikan Depdiknas, Yogyakarta. 